\title{
The effect of the central administration of the Neuropeptide VF on feed intake and its possible interactions with glutamate and opioid systems in broiler chicken
}

\author{
Behnam Hamidi \\ Islamic Azad University \\ Morteza Zendehdel ( $\sim$ zendedel@ut.ac.ir) \\ University of Tehran \\ Bita Vazir \\ Islamic Azad University \\ Ahmad Asghari \\ Islamic Azad University
}

\section{Research Article}

Keywords: Neuropeptide VF, Glutamate, Opioid, Feed intake, Broiler chicks

Posted Date: March 7th, 2022

DOI: https://doi.org/10.21203/rs.3.rs-1398721/v1

License: (c) (1) This work is licensed under a Creative Commons Attribution 4.0 International License.

Read Full License 


\section{Abstract}

Arginine-phenylalanine-amide (RFamide)-related peptides (RFRP) known as neuropeptide VF (NPVF) have a crucial role in feeding regulation. The present study purposed to determine the effect of intracerebroventricular (ICV) injection of the NPVF on dietary intake and possible interactions of NPVF with glutamate and opioid systems in broiler chicken. In experiment 1, chickens received ICV administration of the control solution, NPVF (16 nmol), $15 \mathrm{nmol}$ of MK-801 (NMDA glutamate receptors antagonist), and injection of the NPVF with MK-801 together. In experiments, 2-8 chicken injected intracerebroventricularly with $390 \mathrm{nmol}$ of CNQX (antagonist of AMPA glutamate receptors), $2 \mathrm{nmol}$ of AIDA (an antagonist of mGLUR $_{1}$ glutamate receptors), $150 \mathrm{nmol}$ of LY341495 (an antagonist of mGLUR 2 glutamate receptors), $2 \mathrm{nmol}$ of UBP1112 (an antagonist for mGLUR $_{3}$ glutamate receptors), $5 \mu \mathrm{g}$ of $\beta$ FNA (an antagonist for mu $(\mu$ ) receptors), $5 \mu \mathrm{g}$ of NTI (an antagonist for delta ( $\delta$ ) receptors), nor-BNI (kappa (K) receptors antagonist; $5 \mu \mathrm{g}$ ) instead of MK-801. Following the injection, at 30, 60, and 120 min, the chick's dietary intake was recorded. As a result, NPVF $(16 \mathrm{nmol})$ reduced feed intake in broilers $(P<0.05)$. NPVF + MK-801 co-injection reduced the hypophagic action of the NPVF $(P<0.05)$. Injection of $N P V F+C N Q X$ together reduced the anorectic action of NPVF $(P<0.05)$. Co-injection of NPVF $+\beta-F N A$ reduced effects of NPVF injection $(P<0.05)$. Thus, in newborn broilers, NPVF-induced anorexia is probably mediated by NMDA/ AMPA glutamate and $\mu$ opioid receptors.

\section{Introduction}

Regulation of feeding behavior is a complex and precise process in the body, which requires the coordinated participation of various neurotransmitters (NTs) (Sharkey et al. 2014). (CNS)(Parker et al. 2014). Arginine-phenylalanine-amide (RFamide)-related peptides (RFRP) known as neuropeptide VF (NPVF) encoded by the NPVF gene, which corresponded to humans and animals (Moosadoost et al. 2021). At present, puberty, reproduction (Tsutsui et al. 2010), and appetite regulation (Moosadoost et al. 2021) have also been demonstrated to be affected by this neuropeptide. In this regard, in chicks, intracerebroventricular (ICV) injection of NPVF $(4,8$, and $16 \mathrm{nmol})$ has hypophagic role, according to research (Cline et al. 2008; Moosadoost et al. 2021). It will also be interesting to investigate whether NPVF's connections with NTs regulating feeding affect dietary intake.

Excitatory amino acid neurotransmitter glutamate exists in the CNS, and according to our understanding, two types of its receptors (ionotropic and metabotropic receptors) have been identified. N-Methyl-Daspartate receptor (NMDA), a-amino-3-hydroxy-5-methyl-4-isoxazole propionic acid (AMPA), and Kainate receptors which are ionotropic, while metabotropic receptors are $\mathrm{mGLUR}_{1}, \mathrm{mGLUR}_{2}$, as well as $m G L U R_{3}$ (Ahmadi et al. 2019). According to the previous study (Hettes et al. 2010) (Mortezaei et al. 2013), chickeating behaviors improved and were limited after ICV delivery of NMDA receptor antagonist and AMPA receptors agonist, respectively.

Opioids are known as inhibitory neurotransmitters that have been connected to several acts, including pain adjustment, respiratory function, neuroendocrine and reward situation, and feeding regulation 
(Jaefari-Anari et al. 2018). Nutrition intake was demonstrated to be changed at the time that treatments with opioid receptors agonists such as mu $(\mu)$, delta $(\delta)$, and kappa (к) were started. According to previous investigations, ICV injections of these receptors had orectic and anorectic effects in chickens (Zendehdel et al. 2016). An interaction was reported between NPVF and the opioidergic system on pain modulating. Co-administration of the NPVF with opiates ameliorated their anti-pain effect and limited the progression of opioid-induced hyperalgesia in rats and mice (Elhabazi et al. 2017). Also, RFamide-related peptides related to gonadotropin-inhibitory hormone recreation in mammalian (Wang et al. 2018) and Glutamate fibers, placed near to axons of $\mathrm{GnRH}$, have been documented to arouse and/or prohibit $\mathrm{GnRH}$ secretion and occlude transporter 2 of glutamate in the GnRH neurons (Angelopoulou et al. 2019; Mohapatra et al. 2021).

However, there is no information on the relation of the NPVF with glutamate and opioid systems on food intake in avians. Thus, the present study aimed to indicate the role of ICV injection of the NPVF on dietary intake and its possible interactions with glutamate and opioid systems in broiler chicken.

\section{Materials And Methods}

\section{Animal experiment}

This research included the 352 broilers that were one day of age (Ross-308) and bought from a regional incubation (Morghak Co. Iran). In a temperature of 30 plus $1^{\circ} \mathrm{C}$ and 50 plus 2 percent moisture, chickens were held throughout herds over two days before being randomly sent to single birdhouses (Olanrewaju et al. 2017). The animals were fed a commercialized meal comprising $21 \%$ raw protein and $2850 \mathrm{kcal} / \mathrm{kg}$ of digestible calories (Chineh Co. Iran). During the research, all birds were fed and given new water daily. Just 3 hours before the ICV administration, chickens were food-deprived $\left(\mathrm{FD}_{3}\right)$, but the water was available.

\section{Experimental medicines}

NPVF (neuropeptide VF), MK-801 (antagonist of NMDA glutamate receptors), CNQX (antagonist of AMPA glutamate receptors), AIDA (antagonist of mGLUR $_{1}$ glutamate receptors), LY341495 (antagonist of mGLUR $_{2}$ glutamate receptors), UBP1112 (antagonist of mGLUR $_{3}$ glutamate receptors), $\beta$-FNA (antagonist of $\mu$ receptors), NTI (antagonist of $\delta$ receptors), nor-BNI (antagonist of $\mathrm{k}$ receptors) and Evans Blue bought from Sigma Co. (Sigma, USA). At the first step, the pharmaceuticals were solubilized in absolute dimethyl sulfoxide (DMSO) and diluted in 0.85 percent saline containing Evans blue. The ratio of DMSO was 1/250, which has no harmful impact (Qi et al. 2008).

\section{Methods for ICV administration}


Before each treatment, the birds were dedicated into trial groups based on mean body weight to equal treatment groups as much as feasible. ICV injection applied on day 5 of age utilizing a microsyringe (Hamilton, Switzerland) without anesthesia based on a method defined by Davis et al. (1979) and Furuse et al. (1997) with an acrylic device (Van Tienhoven and Juhasz, 1962). This method, ICV delivery of medicines, had no stress (Saito et al. 2005). Each neonatal chick was examined using an ICV administration (with vehicle or medicine solution) in a volume of $10 \mu \mathrm{L}$ pursued by slicing the frozen brain tissue for the accuracy of the injection site in the ventricle.

\section{Nutrition trials}

Eight experiments were set, with four trial groups: 1-4 ( $n=44$ in each). In experiment 1, chickens received ICV injection of (1) control solution, (2) NPVF (16 nmol), (3) MK-801 (15 nmol), and (4) co-injection of the NPVF + MK-801. In experiment 2, birds were injected with (1) control solution, (2) NPVF (16 nmol), (3) CNQX (390 nmol), and (4) co-injection of the NPVF + CNQX. In experiment 3, chicken received: (1) control solution, (2) NPVF (16 nmol), (3) AIDA (2 nmol) and (4) co-injection of the NPVF + AIDA. In experiment

four, chicks ICV injected with (1) control solution, (2) NPVF (16 nmol), (3) LY341495 (150 nmol), and (4) co-injection of the NPVF + LY341495. In experiment 5, chicks were injected with (1) control solution, (2) NPVF (16 nmol), (3) UBP1112 (2 nmol), and (4) co-injection of the NPVF + UBP1112. In experiment 6, ICV injection of the (1) control solution, (2) NPVF (16 nmol), (3) $\beta$-FNA $(5 \mu \mathrm{g})$, and (4) co-injection of the NPVF + $\beta$-FNA. In trial 7, birds were administrated with (1) control solution, (2) NPVF (16 nmol), (3) NTI (5 $\mu \mathrm{g})$, and (4) co-injection of the NPVF + NTI. In experiment 8, (1) control solution, (2) NPVF (16 nmol), (3) norBNI $(5 \mu \mathrm{g})$, and (4) co-injection of the NPVF + nor-BNI. Chicks with FD3 were instantly sent to their cages and given new water and mash meal. The total nutrition intake (in grams) was recorded at 30,60, and 120 min following the administration. Food intake was calculated as a bodyweight percentage. In each trial group, each chick was only used once.

\section{Statistical analysis}

Accumulated dietary consumption was evaluated as a duplicated measure two-way analysis of variance (ANOVA) utilizing SPSS 16.0 for Windows (SPSS, Inc., Chicago, IL, USA), and the results were presented as mean \pm SEM (standard error of the mean). For treatment having the primary effect by ANOVA, means compared by Tukey-Kramer test $(P<0.05)$.

\section{Results}

ICV delivery of NPVF $(16 \mathrm{nmol})$ reduced feed intake after thirty, sixty, and one hundred and twenty min (P $<0.05$ ). MK-801 (antagonist of NMDA glutamate receptors, $15 \mathrm{nmol}$ ) showed no significant impact on nutrition consumption at thirty, sixty, and one hundred and twenty min following injection $(P>0.05)$. Coinjection of NPVF + MK-801 reduced the hypophagic effect of the NPVF $(P<0.05)($ Fig. 1). 
In contrast to the controls, CNQX (antagonist of AMPA glutamate receptors, $390 \mathrm{nmol}$ ) had no impact on eating behavior following thirty, sixty, and one hundred and twenty min $(P>0.05)$. Central administration of NPVF $(16 \mathrm{nmol})$ reduced dietary consumption after thirty, sixty, and one hundred and twenty min $(\mathrm{P}<$ 0.05). NPVF + CNQX co-injections showed an impact on hypophagia caused by NPVF after thirty, sixty, and one hundred and twenty $\min (P<0.05)$ (Fig. 2).

When compared to the controls in trial III, AIDA (antagonist of mGLUR $_{1}$ glutamate receptors, $2 \mathrm{nmol}$ ) had no impact on eating behavior following thirty, sixty, and one hundred and twenty min $(P>0.05)$. ICV administration of NPVF (16 nmol) reduced feed consumption after thirty, sixty, and one hundred and twenty min $(P<0.05)$. After the combination of NPVF + AIDA, NPVF-induced hypophagia was not influenced after thirty, sixty, and one hundred and twenty minutes $(P>0.05)$ (Fig. 3).

ICV administration of the LY341495 (antagonist of mGLUR $_{2}$ glutamate receptors, $150 \mathrm{nmol}$ ) had no impact on eating behavior following thirty, sixty, and one hundred and twenty min $(P>0.05)$. ICV injection of NPVF $(16 \mathrm{nmol})$ reduced feed intake after thirty, sixty, and one hundred and twenty min $(P<0.05)$. After the combination of NPVF + LY341495, hypophagia of NPVF was not influenced after thirty, sixty, and one hundred and twenty minutes $(P>0.05)$ (Fig. 4).

Thirty, sixty, and one hundred and twenty min after administration, UBP1112 (antagonist of mGLUR 3 glutamate receptors, $2 \mathrm{nmol})$ did not reduce chick-eating relative to the controls, as shown in trial 5 ( $P$ > 0.05). ICV delivery of NPVF $(16 \mathrm{nmol})$ reduced feed intake after thirty, sixty, and one hundred and twenty $\min (P<0.05)$. Thirty, sixty, and one hundred and twenty min after NPVF administration, UBP1112 showed no impact on hypophagia caused by NPVF (P>0.05) (Fig. 5).

Compared to controls, $\beta$-FNA (antagonist of $\mu$ receptors, $5 \mu \mathrm{g}$ ) injections given showed no significant impact on food consumption following thirty, sixty, and one hundred and twenty min $(P>0.05)$. ICV injection of NPVF $(16 \mathrm{nmol})$ reduced chick-eating after thirty, sixty, and one hundred and twenty min $(\mathrm{P}<$ $0.05)$. The combination of the NPVF plus $\beta$-FNA substantially impacted NPVF -induced hypophagia $(P<$ 0.05) (Fig. 6).

ICV injection of the NTI (antagonist of $\delta$ receptors, $5 \mu \mathrm{g}$ ) had no impact on eating behavior following thirty, sixty, and one hundred and twenty min $(P>0.05)$. ICV injection of NPVF $(16 \mathrm{nmol})$ reduced chickeneating after thirty, sixty, and one hundred and twenty min $(P<0.05)$. After administration of NPVF + NTI, hypophagia of NPVF was not influenced after thirty, sixty, and one hundred and twenty minutes $(P>0.05)$ (Fig. 7).

Injection of the nor-BNI (antagonist of $\mathrm{k}$ receptors, $5 \mu \mathrm{g}$ ) had no impact on eating behavior following $(\mathrm{P}>$ 0.05). ICV injection of NPVF $(16 \mathrm{nmol})$ reduced feed intake after thirty, sixty, and one hundred and twenty min $(P<0.05)$. The combination of the NPVF with nor-BNI was not influenced hypophagia by NPVF after thirty, sixty, and one hundred and twenty minutes $(P>0.05)$ (Fig. 8).

\section{Discussion}


To the best of our knowledge, this is the first work aiming at ICV injection of the NPVF on dietary intake and its possible interactions with glutamate and opioid systems in broiler chicken. The induced balance between dietary intake and energy consumption resulting in the interaction of peripheral inputs with CNS is known as energy homeostasis. NTs and their regulatory nexus have a pivotal role in energy homeostasis in this regard (Rahmani et al. 2021). Based on the results obtained, NPVF (16 nmol) can induce decreased feed intake in broilers after three hours of feeding restriction. NPVF has a high affinity to the NPFF1 receptor and affects eating behavior in animals (Tachibana et al. 2005; 2007). It is found that ICV delivery of RFRP-3 promoted rat eating (Murakami et al. 2008). RFRP-1 and RFRP-3, on the other hand, limited chick-eating (Newmyer and Cline. 2009; Cline et al. 2008). Observed differences might have related to millions of years' discrepancy on evolution between avian and mammalian (Hassanpour et al. 2015). Neurons of RFRP-3 are projected to the POMC and agouti-related peptide (AgRP) neurons which are placed in the arcuate nucleus, and it is a well-known fact that both neuron nexus have a crucial role in relish and dietary consumption control in avians (Moosadoost et al. 2021). Further, it is suggested that anorexigenic peptides such as a melanocyte-stimulating hormone or glucagon-like peptide-1 have an important role than the hypothalamic-pituitary-adrenal axis for the temporary anorexia of RFamides (Cline et al. 2008). For instance, Moosadoost et al. (2021) reported that ICV injection of the RFRP-3 (4, 8, and $16 \mathrm{nmol}$ ) significantly decreased feeding in broiler chicken, and our result agrees with this report.

As observed, co-injection of NPVF + NMDA receptors antagonist reduced the anorectic effect of the NPVF. Also, the combination of NPVF + AMPA receptors antagonist reduced the anorectic effect of NPVF while $\mathrm{MGLUR}_{1} / \mathrm{mGLUR}_{2} / \mathrm{mGLUR}_{3}$ glutamate receptors antagonists did not affect NPVF-induced hypophagia. Further, in previous studies, ICV injection of MK-801, CNQX, and $\beta$-FNA had a regulatory impact on NTs involved in dietary intake in chicks; however, AIDA, LY341495, UBP1112 had no effect (Mobarhan et al. 2021; Adeli et al. 2020; Mortezaei et al. 2013). It appears that there is a connection between glutamate and NPVF on eating behavior resulting from an association between the NPVF and glutamate. According to this notion, the blockage of transporter 2 of glutamate in the GnRH neurons is influenced by RFamiderelated peptides (Mohapatra et al. 2021).

Co-injection of NPVF plus $\mu$-receptors antagonist reduced effects of NPVF injection. $\delta / \mathrm{k}$ receptors antagonist, on the other hand, did not influence NPVF -induced hypophagia. Also, in a previous investigation, ICV administration of MK-801, CNQX, and $\beta$-FNA had a regulatory impact on NTs in feeding neonatal chicks; however, AIDA, LY341495, UBP1112, and NTI had none (Raji- Dahmardeh et al. 2020). It turns out to be an interaction between opioids and NPVF on dietary intake behavior, based on a relationship between the NPVF and analgesic effects of opiates. In this view, it is reported that the function of the opioidergic system is modulated by antagonizing the neuropeptide FF (NPFF) receptors. Activation of NPFF receptors decreases the anti-pain impacts of opiates and prevents conditioned test preferences caused by morphine (Kim et al. 2016). In addition, $\mu$-opioids suppresses vasopressin and oxytocin neurons in the hypothalamic supraoptic nucleus. NPFF receptors and $\mu$-receptors are both expressed in the supraoptic nucleus. It is assumed that RFRP-3 notably alleviates the prohibitory impact of morphine on both neurons of vasopressin and oxytocin (Kim et al. 2016). Also, on the report of 
previous discoveries, it has been indicated that opioid receptors can affect NPFF-induced rat-eating behavior (Nicklous and Simansky, 2003).

The results showed that in chicks, NPVF-induced hypophagia was mediated by NMDA/AMPA and $\mu$ receptors. However, further investigation is remained to be determined the key cellular and molecular signaling pathways in the links between NPVF-induced hypophagia with NMDA / AMPA glutamate and $\mu$ opioid receptors in chick feeding behavior.

\section{Declarations}

\section{Acknowledgments}

The authors would like to express their deepest gratitude to the central laboratory (Dr. Rastegar Lab.) of the Faculty of Veterinary Medicine, the University of Tehran, for cooperation. This study was obtained from a Ph.D. thesis performed by the first author.

Author Contributions Behnam Hamidi, Morteza Zendehdel, Bita Vazir, and Ahmad Asghari wrote the main manuscript text and prepared figures 1-8. All authors reviewed the manuscript. The work is original and not previously published. All data are true and accurate to the knowledge of the authors.

Data availability Data will be made available upon request.

\section{Compliance with Ethical Standards}

Conflict of interest Authors has no potential conflicts of interest.

Informed Consent This manuscript does not contain any studies with human subjects performed by any authors.

Research Involving Human and/or Animals Rights All experiments were executed according to the Guide for the Care and Use of Laboratory Animals and were approved by the institutional animal ethics committee.

\section{Funding}

The authors did not receive support from any organization for the submitted work.

\section{References}

1. Adeli A, Zendehdel M, Babapour V, Panahi N (2020) Interaction between leptin and glutamatergic system on food intake regulation in neonatal chicken: role of NMDA and AMPA receptors. Int $J$ Neurosci 130(7):713-721)

2. Ahmadi F, Zendehdel M, Babapour V, Panahi N (2019) CRF1/CRF2 and MC3/MC4 receptors affect glutamate-induced food intake in neonatal meat-type chicken. Brazilian J Poult Sci 21(1). 
doi.org/10.1590/1806-9061-2018-0821

3. Angelopoulou E, Quignon C, Kriegsfeld LJ, Simonneaux V (2019) Functional implications of RFRP-3 in the central control of daily and seasonal rhythms in reproduction. Frontiers in endocrinology. 10;10:183. doi: 10.3389/fendo.2019.00183. PMID: 31024442; PMCID: PMC6467943

4. Cline MA, Bowden CN, Calchary WA, Layne JE (2008) Short-Term Anorexigenic Effects of Central Neuropeptide VF are Associated with Hypothalamic Changes in Chicks. J Neuroendocrinol 20(8):971-977. https://doi.org/10.1111/j.1365-2826.2008.01749.x

5. Cline MA, Bowden CN, Calchary WA, Layne JE (2008) Short-Term Anorexigenic Effects of Central Neuropeptide VF are Associated with Hypothalamic Changes in Chicks. J Neuroendocrinol 20(8):971-977. https://doi.org/10.1111/j.1365-2826.2008.01749.x

6. Davis JL, Masuoka DT, Gerbrandt LK, Cherkin AA (1979) Autoradiographic distribution of L- proline in chicks after intracerebral injection. Physiol Behav 22:693-695

7. Elhabazi K, Humbert JP, Bertin I, Quillet R, Utard V, Schneider S, Schmitt M, Bourguignon JJ, Laboureyras E, Boujema MB, Simonnet G (2017) RF313, an orally bioavailable neuropeptide FF receptor antagonist, opposes effects of RF-amide-related peptide-3 and opioid-induced hyperalgesia in rodents. Neuropharmacology 15:118188-118198

8. Furuse M, Matsumoto M, Saito N, Sugahara K, Hasegava S (1997) The central corticotropin-releasing factor and glucagon-like peptide - 1 in food intake of the neonatal chick. Eur J Pharmacol 339:211214

9. Hassanpour S, Zendehdel M, Babapour V, Charkhkar S (2015) Endocannabinoid and nitric oxide interaction mediates food intake in neonatal chicken. Br Poult Sci 56(4):443-451. https://doi.org/10.1080/00071668.2015.1059407

10. Hettes SR, GonzagaWJ, Heyming TW, Nguyen JK, Perez S, Stanley BG (2010) Stimulation of lateral hypothalamic AMPA receptors may induce feeding in rats. Brain Res 1346:112-120

11. Jaefari-Anari M, Zendehdel M, Gilanpour H, Asghari A, Babapour V (2018) Central opioidergic system interplay with histamine on food intake in neonatal chicks: role of $\mu$-opioid and $\mathrm{H} 1 / \mathrm{H} 3$ receptors. Brazilian J Poult Sci 20:595-604

12. Kim JS, Brown CH, Anderson GM (2018) Anti-opioid effects of RFRP-3 on magnocellular neuron activity in morphine-naïve and morphine-treated female rats. Endocrinology. 2016 Oct 1;157(10):4003-11

13. Mobarhan Fard M, Vazir B, Zendehdel M, Asghari A (2021) Interaction of Central Glutamatergic and Histaminergic Systems on Food Intake Regulation in Layer Chickens. Arch Razi Inst 76(3):537-551)

14. Mohapatra SS, Mukherjee J, Banerjee D, Das PK, Ghosh PR, Das K (2021) RFamide peptides, the novel regulators of mammalian HPG axis: A review. Veterinary World 14(7):1867-1873

15. Moosadoost Y, Zendehdel M, Khodadadi M (2021) The Effect of RFamide-Related Peptide-3 (RFRP-3 or NPVF) on Food Intake in Neonatal Chickens: The Role of MC3/MC4 and CRF 1/CRF 2 Receptors. Int J Pept Res Ther 27:253-262 
16. Mortezaei SS, Zendehdel M, Babapour V, Hasani K (2013) The role of glutamatergic and GABAergic systems on serotonin- induced feeding behavior in chicken. Vet Res Commun 37:303-310

17. Murakami M, Matsuzaki T, Iwasa T, Yasui T, Irahara M, Osugi T, Tsutsui K (2008) Hypophysiotropic role of RFamide-related peptide-3 in the inhibition of LH secretion in female rats. J Endocrinol 199(1):105-112. https://doi.org/10.1677/JOE-08-0197

18. Newmyer BA, Cline MA (2009) Neuropeptide SF is associated with reduced food intake in chicks. Behav Brain Res 205(1):311-314. https://doi.org/10.1016/j.bbr.2009.06.013

19. Nicklous DM, Simansky KJ (2003) Neuropeptide FF exerts pro-and anti-opioid actions in the parabrachial nucleus to modulate food intake. Am J Physiology-Regulatory Integr Comp Physiol 285(5):1046-1054)

20. Olanrewaju HA, Purswell J, Collier SD, Branton SL (2017) Effects of light ingress through ventilation fan apertures on selected blood variables of male broilers. Int J Poult Sci 16:288-295

21. Parker KE, Johns HW, Floros TG, Will MJ (2014) Central amygdala opioid transmission is necessary for increased high-fat intake following 24-h food deprivation, but not following intra-accumbens opioid administration. Behav Brain Res 260:131-138. https://doi.org/10.1016/j.bbr.2013.11.014

22. Qi W, Ding D, Salvi RJ (2008) Cytotoxic effects of dimethyl sulphoxide (DMSO) on cochlear organotypic cultures. Hear Res 236:52-60

23. Rahmani B, Ghashghayi E, Zendehdel M, Khodadadi M, Hamidi B (2021) The Crosstalk Between Brain Mediators Regulating Food Intake Behavior in Birds: A Review. Int J Pept Res Ther 27:23492370

24. Raji-Dahmardeh F, Vazir B, Zendehdel M, Asghari A, Panahi N (2020) Interaction Between Oxytocin and Opioidergic System on Food Intake Regulation in Neonatal Layer Type Chicken. Int J Pept Res Ther 26:1905-1912)

25. Saito ES, Kaiya H, Tachibana T, Denbow DM, Kangawa K, Furuse M (2005) Inhibitory effect of ghrelin on food intake is mediated by the corticotropin-releasing factor system in neonatal chicks. Regul Pept 125:201-208

26. Sharkey KA, Darmani NA, Parker LA (2014) Regulation of nausea and vomiting by cannabinoids and the endocannabinoid system. Eur J Pharmacol 722:134-146. https://doi.org/10.1016/j.ejphar.2013.09.068

27. Tachibana T, Sato M, Oikawa D, Takahashi H, Boswell T, Furuse M (2007) The anorexic effect of amelanocyte-stimulating hormone is mediated by corticotrophin releasing factor in chicks. Comp Biochem Physiol A Mol Integr Physiol 147:173-178. https://doi.org/10.1016/j.cbpa.2006.12.044

28. Tachibana T, Sato M, Takahashi H, Ukena K, Tsutsui K, Furuse M (2005) Gonadotrophin-inhibiting hormone stimulates feeding behavior in chicks. Brain Res 1050:94-100. https://doi.org/10.1016/j.brainres.2005.05.035

29. Tsutsui K, Bentley GE, Kriegsfeld LJ, Osugi T, Seong JY, Vaudry H (2010) Discovery and evolutionary history of gonadotrophin-inhibitory hormone and kisspeptin: new key neuropeptides controlling reproduction. J Neuroendocrinol 22(7):716-727. https://doi.org/10.1111/j.1365-2826.2010.02018.x 
30. Van Tienhoven A, Juhasz LP (1962) The chicken telencephalon, diencephalon and mesencephalon in sterotaxic coordinates. J Comp Neurol 118:185-197

31. Wang H, Khoradmehr A, Jalali M, Salehi MS, Tsutsui K, Shirazi MR, Tamadon A (2018) The roles of RFamide-related peptides (RFRPs), mammalian gonadotropin-inhibitory hormone $(\mathrm{GnlH})$ orthologues in female reproduction. Iran J basic Med Sci 21(12):1210

32. Zendehdel M, Ghashghayi E, Hassanpour S, Baghbanzadeh A, Jonaidi H (2016) Interaction between opioidergic and dopaminergic systems on food intake in neonatal layer type chicken. Int J Pept Res Ther 22:83-92

\section{Figures}

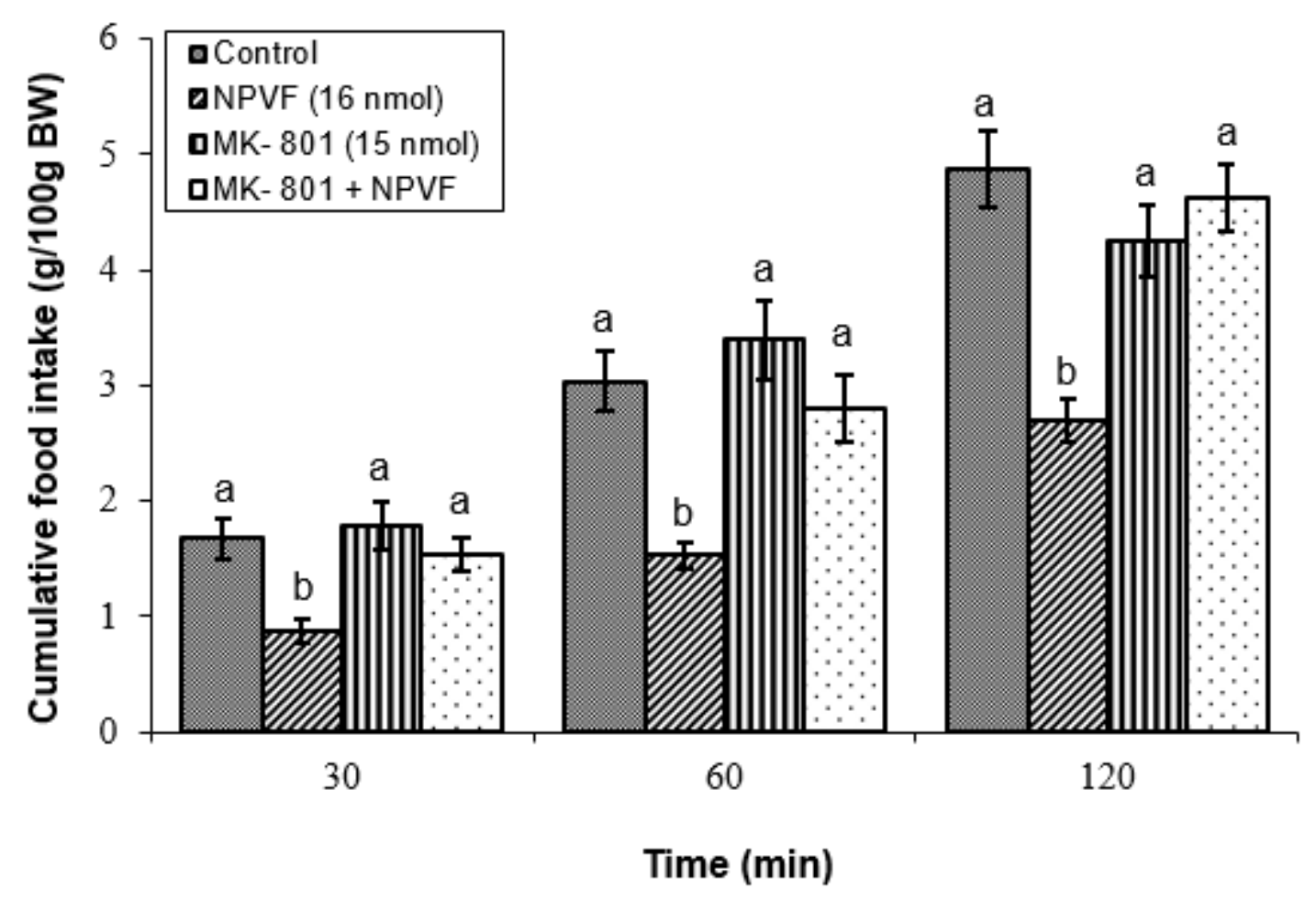

Figure 1

Effects of intracerebroventricular injection of control solution, NPVF (neuropeptide VF; $16 \mathrm{nmol}$ ), MK-801 (NMDA glutamate receptors antagonist; $15 \mathrm{nmol}$ ), and co-injection of the NPVF plus MK-801 on cumulative food intake $(\mathrm{g} / 100 \mathrm{~g} \mathrm{BW})$ in neonatal meat-type chicks. Data are expressed as mean $\pm \mathrm{SEM}$. Different letters $(\mathrm{a}, \mathrm{b}$, and $\mathrm{c})$ indicate significant differences between treatments at each time $(P<0.05)$ 


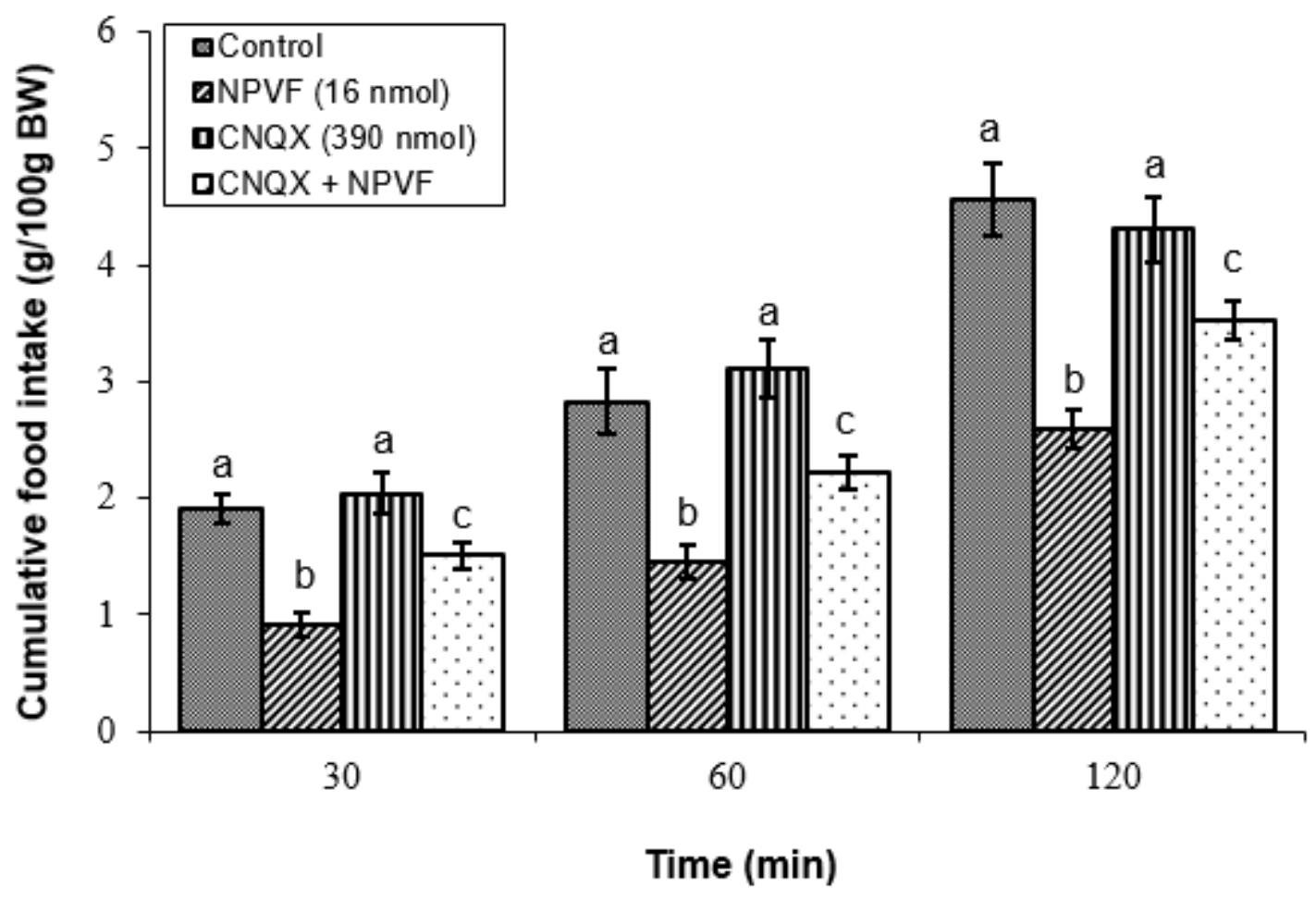

Figure 2

Effects of intracerebroventricular injection of control solution, NPVF (neuropeptide VF; $16 \mathrm{nmol}$ ), CNQX (AMPA glutamate receptors antagonist; $390 \mathrm{nmol}$ ), and co-injection of the NPVF plus CNQX on cumulative food intake $(\mathrm{g} / 100 \mathrm{~g} \mathrm{BW})$ in neonatal meat-type chicks. Data are expressed as mean \pm SEM. Different letters $(a, b$, and $c)$ indicate significant differences between treatments at each time $(P<0.05)$ 


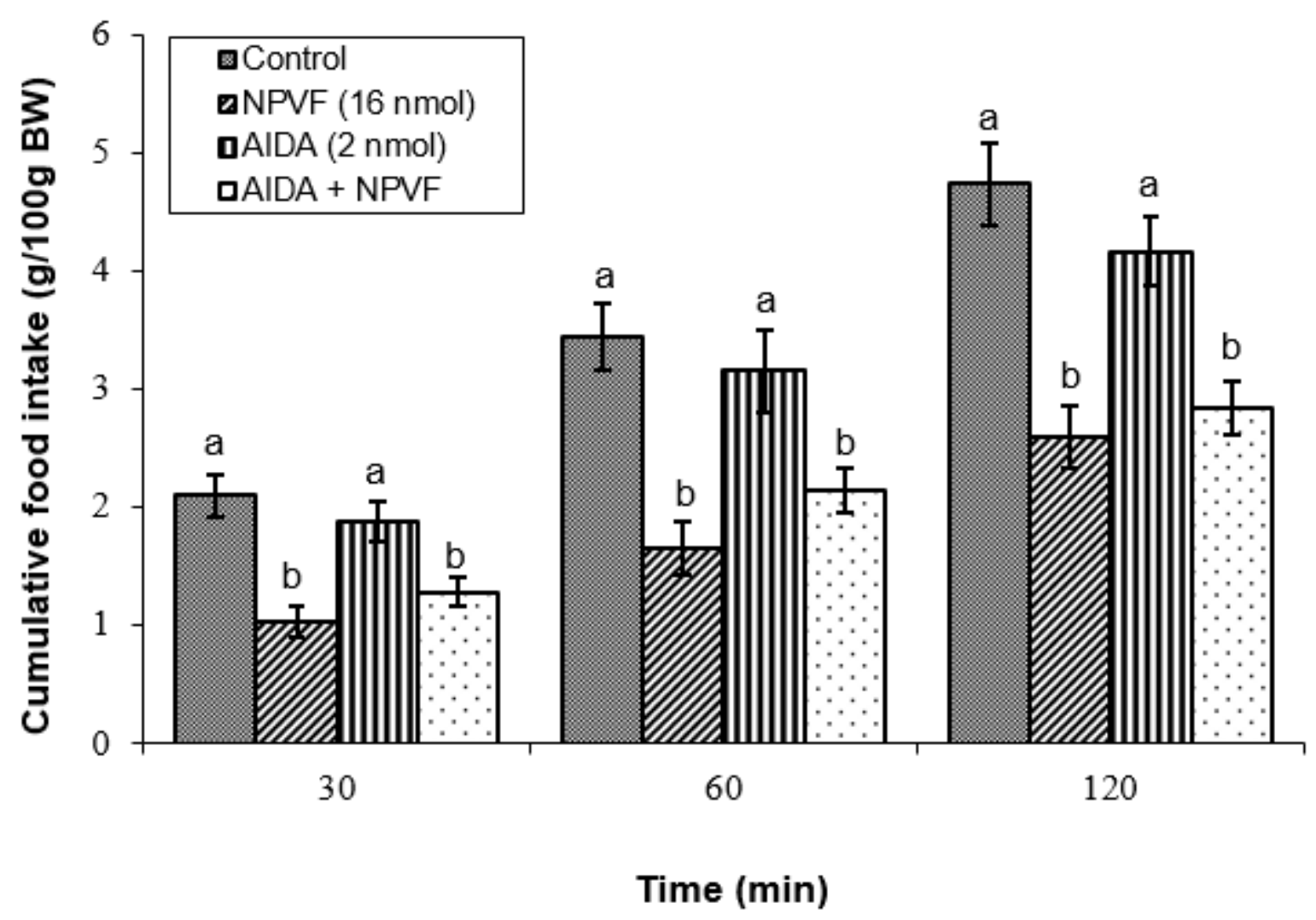

Figure 3

Effects of intracerebroventricular injection of control solution, NPVF (neuropeptide VF; $16 \mathrm{nmol}$ ), AIDA ( $\mathrm{mGLUR}_{1}$ glutamate receptors antagonist; $2 \mathrm{nmol}$ ), and co-injection of the NPVF plus AIDA on cumulative food intake $(\mathrm{g} / 100 \mathrm{~g} \mathrm{BW})$ in neonatal meat-type chicks. Data are expressed as mean $\pm \mathrm{SEM}$. Different letters $(\mathrm{a}$ and $\mathrm{b})$ indicate significant differences between treatments at each time $(P<0.05)$ 


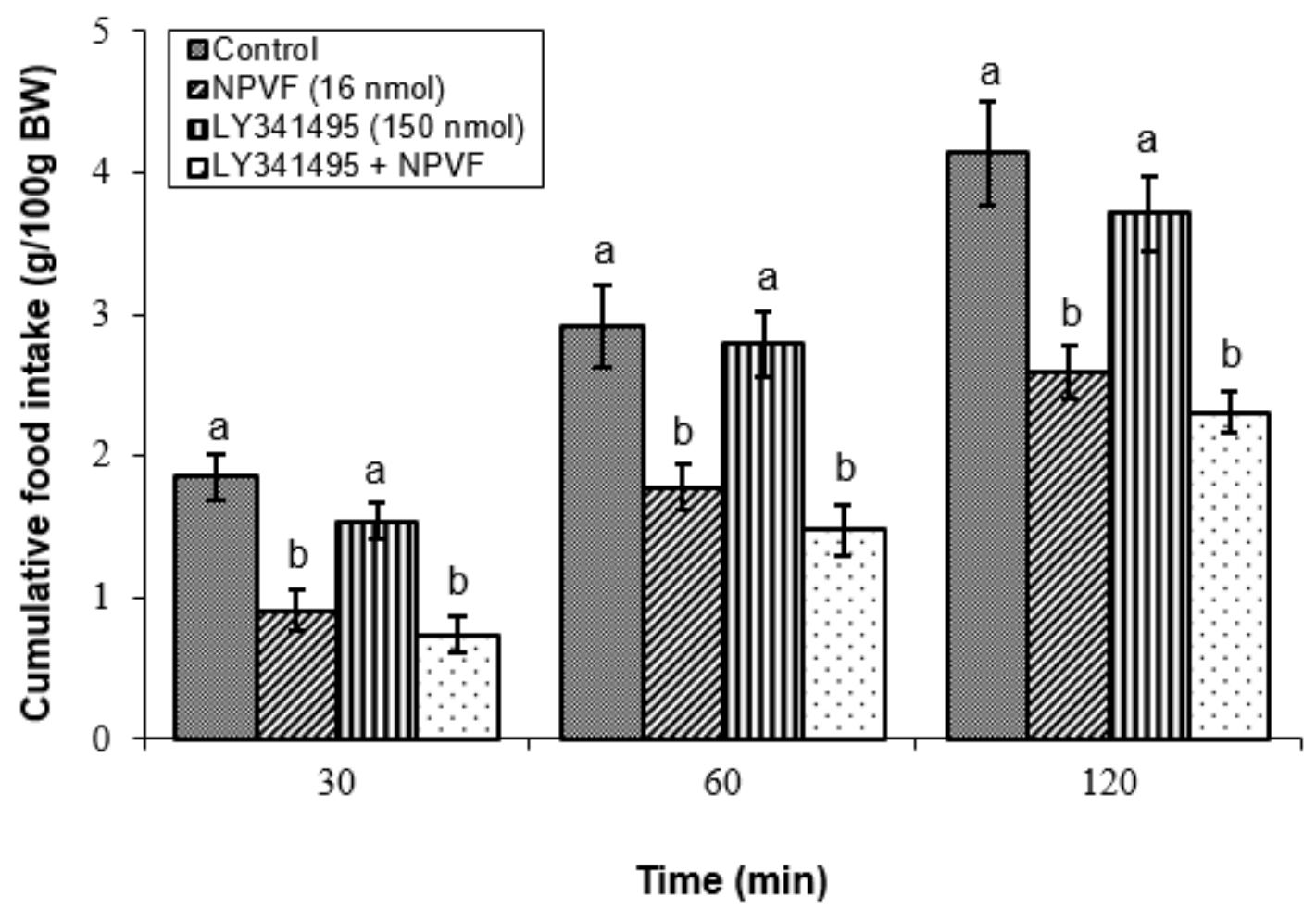

Figure 4

Effects of intracerebroventricular injection of control solution, NPVF (neuropeptide VF; $16 \mathrm{nmol}$ ), LY341495 (mGLUR 2 glutamate receptors antagonist; $150 \mathrm{nmol}$ ), and co-injection of the NPVF plus LY341495 on cumulative food intake $(\mathrm{g} / 100 \mathrm{~g} \mathrm{BW})$ in neonatal chicks. Data are expressed as mean \pm SEM. Different letters $(a$ and $b)$ indicate significant differences between treatments at each time $(P<$ 0.05) 


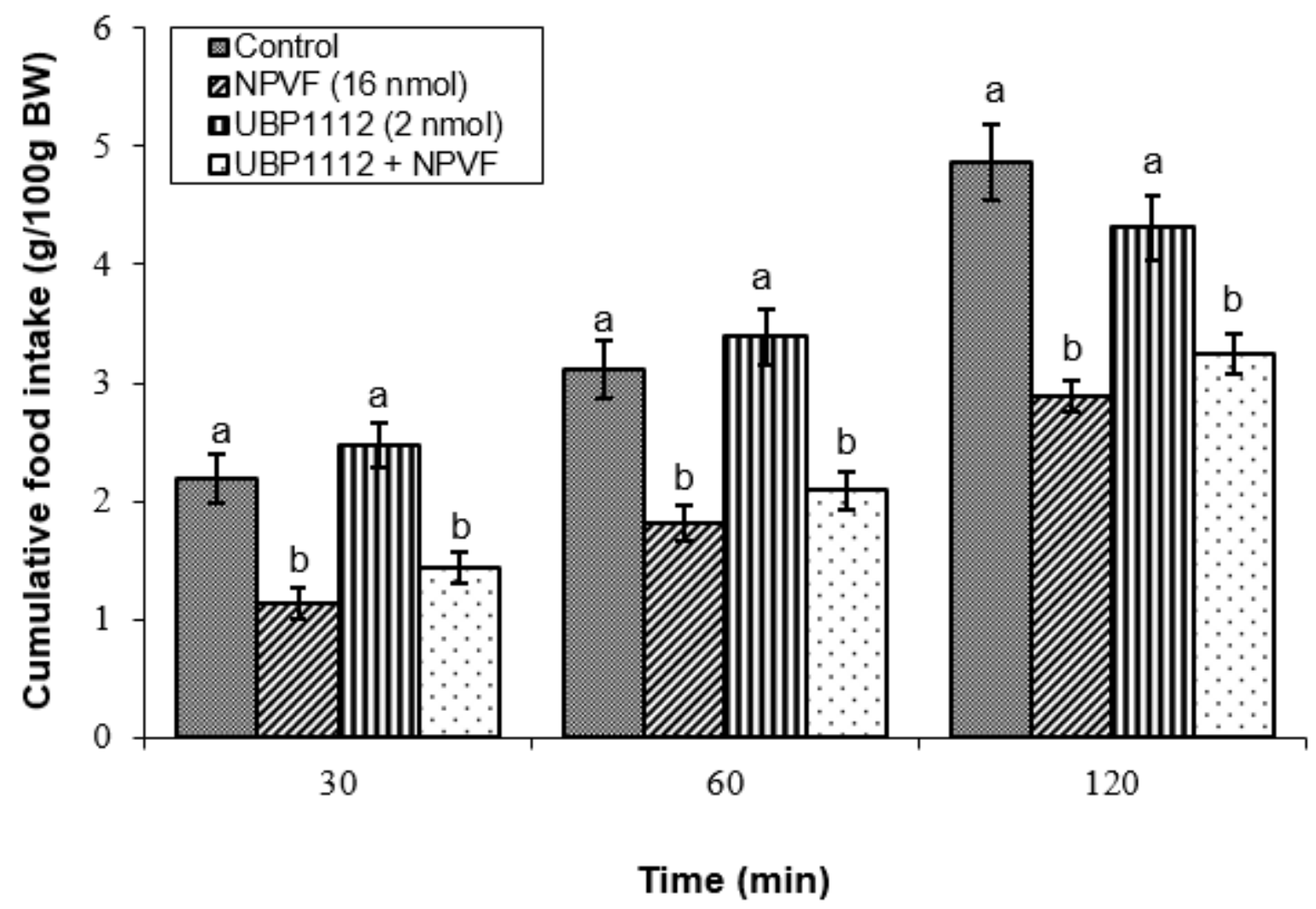

Figure 5

Effects of intracerebroventricular injection of control solution, NPVF (neuropeptide VF; $16 \mathrm{nmol}$ ), UBP1112 ( $\mathrm{mGLUR}_{3}$ glutamate receptors antagonist; $2 \mathrm{nmol}$ ), and co-injection of the NPVF plus UBP1112 on cumulative food intake ( $\mathrm{g} / 100 \mathrm{~g} \mathrm{BW})$ in neonatal meat-type chicks. Data are expressed as mean \pm SEM. Different letters ( $a$ and $b)$ indicate significant differences between treatments at each time $(P<$ 0.05) 


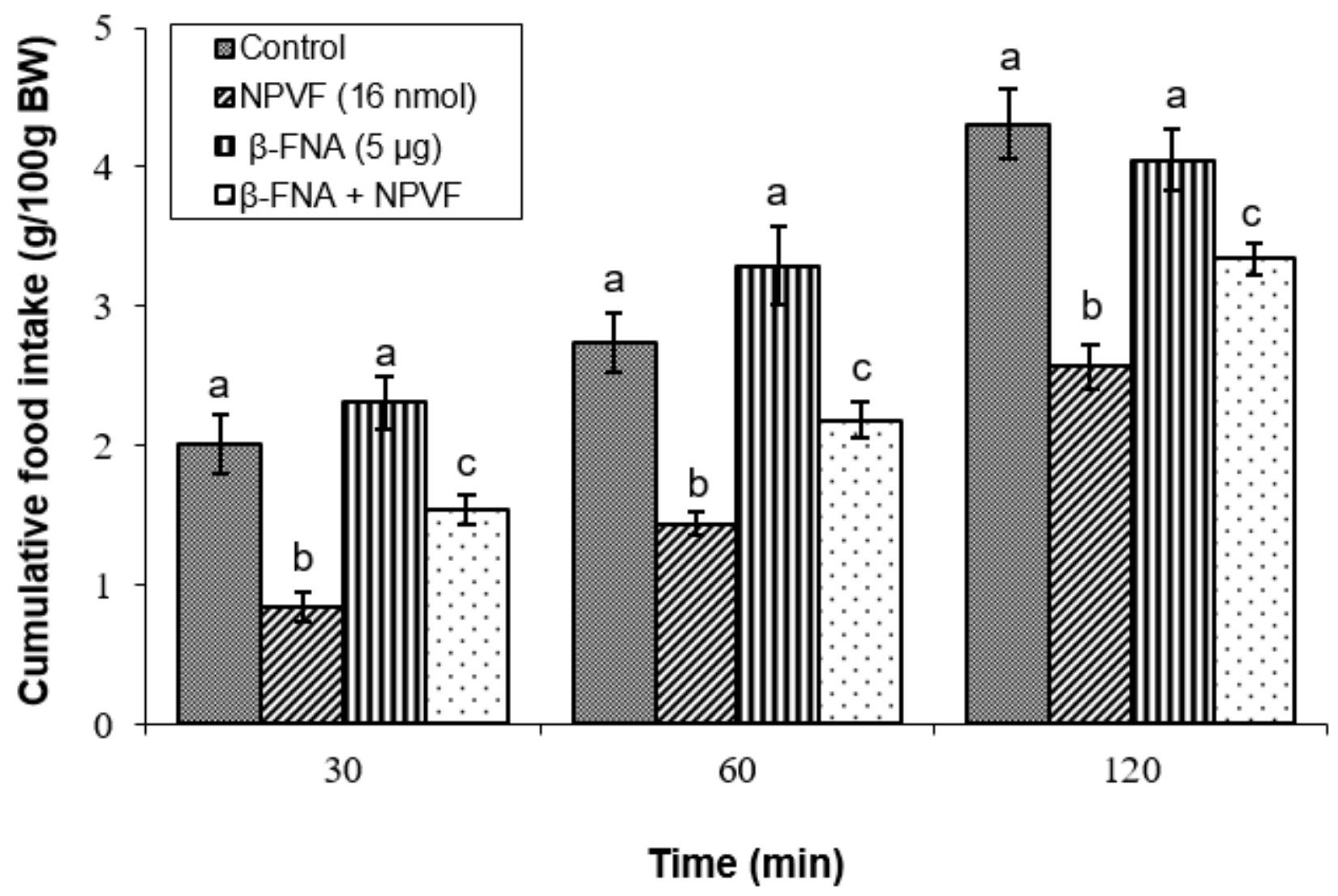

Figure 6

Effects of intracerebroventricular injection of control solution, NPVF (neuropeptide VF; $16 \mathrm{nmol}$ ), $\beta$-FNA (mu receptors antagonist; $5 \mu \mathrm{g}$ ), and co-injection of the NPVF plus $\beta$-FNA on cumulative food intake $(\mathrm{g} / 100 \mathrm{~g} \mathrm{BW})$ in neonatal meat-type chicks. Data are expressed as mean \pm SEM. Different letters (a and $b)$ indicate significant differences between treatments at each time $(P<0.05)$ 


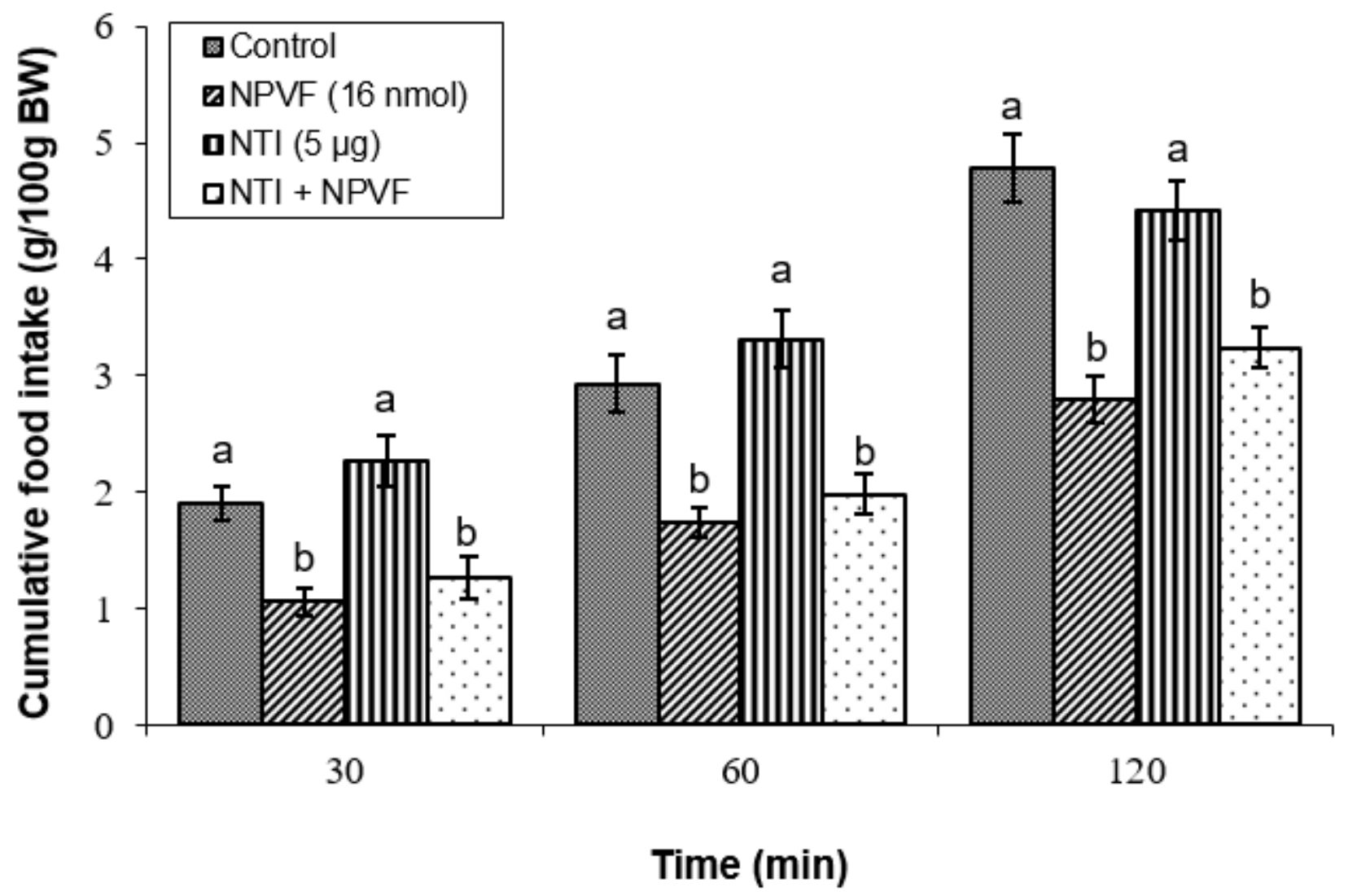

Figure 7

Effects of intracerebroventricular injection of control solution, NPVF (neuropeptide VF; $16 \mathrm{nmol}$ ), NTI (delta receptors antagonist; $5 \mu \mathrm{g}$ ), and co-injection of the NPVF plus NTI on cumulative food intake $(\mathrm{g} / 100 \mathrm{~g} \mathrm{BW})$ in neonatal meat-type chicks. Data are expressed as mean \pm SEM. Different letters (a and $b)$ indicate significant differences between treatments at each time $(P<0.05)$ 


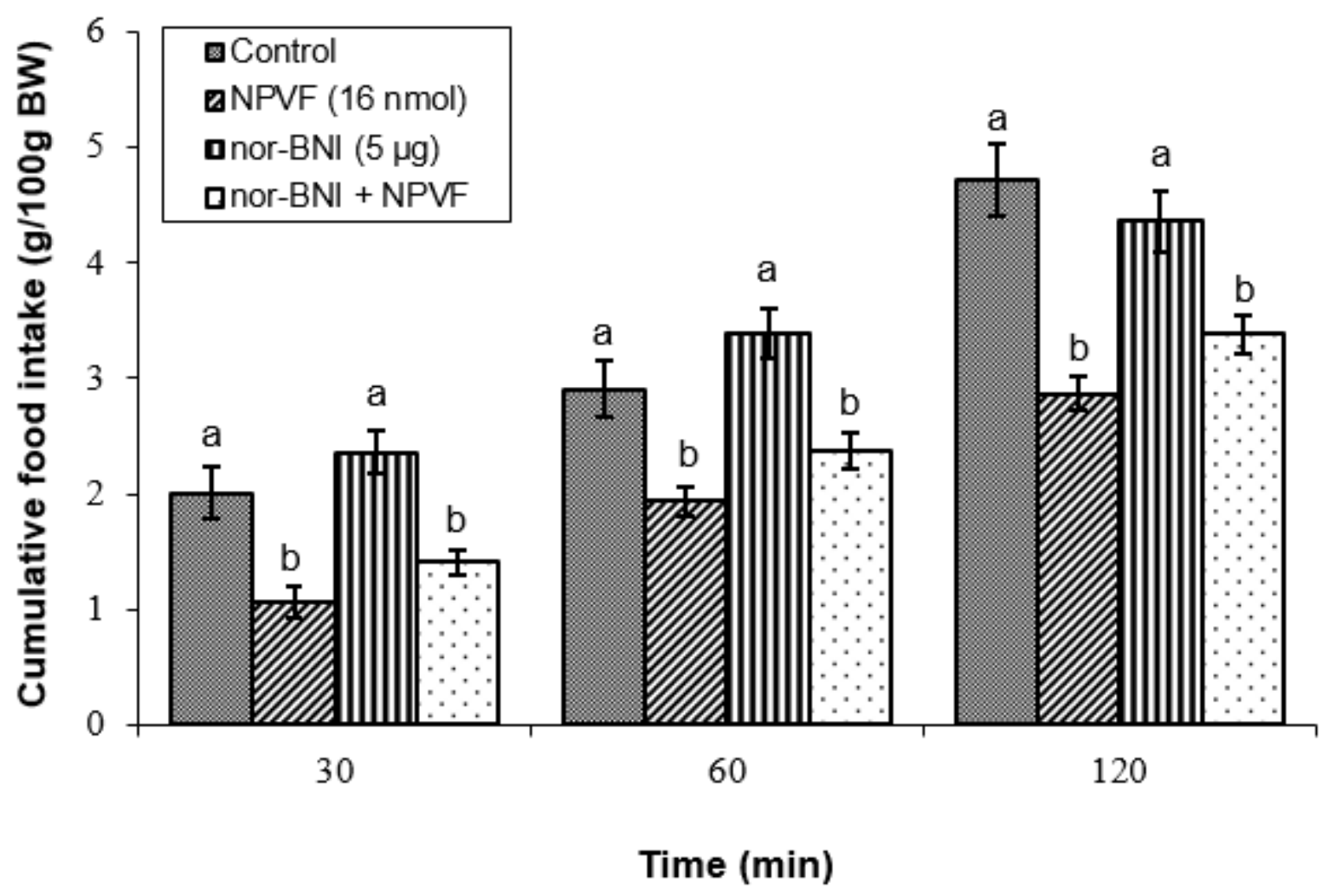

Figure 8

Effects of intracerebroventricular injection of control solution, NPVF (neuropeptide VF; $16 \mathrm{nmol}$ ), nor-BNI (kappa receptors antagonist; $5 \mu \mathrm{g}$ ), and co-injection of the NPVF plus nor-BNI on cumulative food intake (g/100g BW) in neonatal meat-type chicks. Data are expressed as mean \pm SEM. Different letters $(a$ and $b)$ indicate significant differences between treatments at each time $(P<0.05)$ 